\title{
A Comparative Overview of the Verbal System in Albanian and Greek
}

\author{
Dr. Mirela Xhaferraj (Mitro)
}

University of Tirana, Albania

Email:mirelaxhaferraj@yahoo.com

\section{Dr. Daniela Hasa}

University of Tirana, Albania

Email: hasadaniela@gmail.com

\section{Doi:10.5901/jesr.2014.v4n6p103}

\begin{abstract}
The Albanian and Greek languages have a diverse verbal system with a wide variety of tense and mood forms. This system in both languages has evolved from the Indo-European language where in some cases it has preserved some of its features and in other cases it has had an independent development in the respective languages. The verbs in both languages, Albanian and Greek, display a variety of grammatical forms which follow a certain paradigm when used in a sentence. These forms bear similarities either as a result of the common Indo-European source or as a result of the independent development of each language; still, there are also some differences. A general comparative overview of the verbal system in both languages, which identifies these similar features and differences, will be the subject of this article.
\end{abstract}

Keywords: verb, conjugation, mood, tense, Greek, Albanian.

\section{Introduction}

Albanian and Greek bear many similarities as well as peculiarities at the lexical and grammatical levels. The verbal system, the main grammatical level in both languages is quite rich in tense and mood forms. This system has undergone significant changes as compared to the old Indo-European system. According to Topalli (2010), Greek being a conservative language has undergone fewer changes by preserving the old system, whereas Albanian being more innovative has changed more this system. Some of these changes have followed the same track that the majority of Indo-European languages have followed, whereas other changes are language specific.

Similar to other Indo-European languages the verbal inflexions in Albanian are re-organized according to the conjugation features, which are different from one language to the other regarding the details, however, all these languages have in common the fact that the verbs display a wide variety of grammatical forms according to a specific paradigm (Sh. Demiraj: 1976) when used in different contexts. During its evolution, the verbal system has been entirely re-organized, where in the majority of the cases this evolution has been carried out before the written period and it is conditioned by the re-organization of the grammatical categories of the verbal system (Sh. Demiraj: 2002). Many old forms of the Indo-European type have disappeared such as the augment inherited in Modern Greek. In the classical period Greek, almost all verbs changed the initial sound of the stem in all forms of the past tense, so if the initial sound of the stem was a consonant, it was preceded by the vowel $\varepsilon$-, if the initial sound of the stem was a vowel, then the vowel

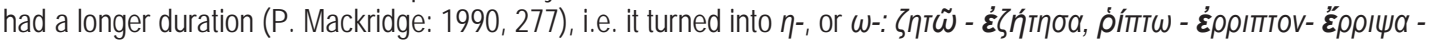

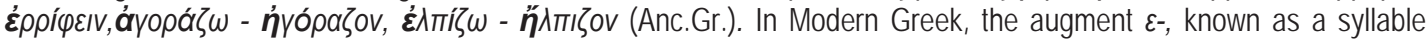
augment is added to the stem of the verbs, which have a consonant as an initial sound as well as to two-syllable verbs, when they form the past progressive tense and the aorist of the active indicative mood, apart from the verbs of the second conjugation. According to Klairis and Babiniotis $(2004,526)$, the role of the augment in Modern Greek is of a morpho-phonological character which helps to stress the verbs. Another Indo-European element which has been avoided is the dual number, which was used also for the nominal system and in Albanian we have the opposition singular - plural. Traces of the dual number are not present in the recorded documents of Albanian (Sh. Demiraj: 1976, 116). The dual number is present in both Ancient and Modern Greek, while in Albanian it has disappeared.

Another old Indo-European phenomenon which is still present in some of the old verbs of Albanian is suppletion, 
for example jam - qeshë (am - was), shoh - pashë (see - saw) etc. The same phenomenon is present in both Ancient

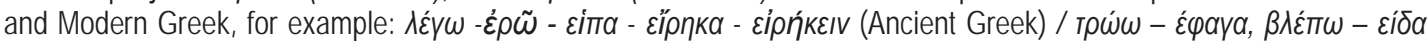
(Modern Greek).

Another inherited feature is the form of the sigmatic aorist, which is present in Albanian only in the first person of some old verbs such as dhashë (gave), while it is present in both Ancient and Modern Greek, where some verbs form the sigmatic aorist with the final consonant of the aorist stem $-\sigma-,-\psi-,-\xi-$, while others form the non-sigmatic aorist.

The recorded Albanian verbal system has undergone significant changes both in terms of the types of conjugations and also regarding the construction of the verbal stems, thus, with regard to -mi conjugation, the old athematic conjugation, there are present only some verbs jam, kam and thom (Sh. Demiraj: 2002, 300). The $-\mu$ I conjugation was present in Ancient Greek, where words ending in $-\mu$ । belonged to the second conjugation, whereas words ending in $-\omega$ belonged to the first conjugation, while in Modern Greek there are not any verbs corresponding to this conjugation, all verbs in active end in $-\omega$.

In the course of their evolution, new forms have been created in both languages of an analytical character. Thus, in Albanian we have the forms of the present and past perfect tense (kam lexuar (have read), kisha lexuar (had read) etc., forms of the future tenses, the analytical forms of the subjunctive, the non-finite forms constructed on the basis of the past participle, the passive constructions with the particle $u$, the non-finite forms formed on the basis of neutral verbal nouns, the analytical forms with the value of the aspect (po punoj, jam duke punuar (I am working) and some analytical verb forms of a modality character which express obligation and possibility (do bërë (should be done), duhet bërë (must be done), mund të bëhet (can be done) (K. Topalli: 2010, 58-60).

The analytical present perfect (past perfect) forms constructed with the verb kam (have) and the past participle of the main verb is a common feature, not only for the non-slavic languages of the Balkans, but it is also present in western Macedonian (Sh. Demiraj: 2004,167). In Ancient Greek, both the present perfect and the past perfect were synthetically formed with the suffixes $-\boldsymbol{K} \boldsymbol{\alpha}$ and $-\boldsymbol{K} \boldsymbol{\varepsilon} \boldsymbol{I} \boldsymbol{V}$ respectively.

The analytical form of the future do të punoj (will work) is formed as a result of the grammaticalization of the verb dua (want) in the form do with the subjunctive present tense, which is a phenomenon present in Greek as well. In the Ancient Greek, the future tense was formed synthetically where the inflexions of the active and medium forms of the

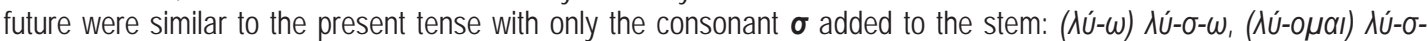
$o \mu a I, \lambda \varepsilon \lambda u ́-\sigma-o \mu a l \cdot$ which had a tense character, whereas the passive was formed by adding the syllable $\theta \eta$ and then the

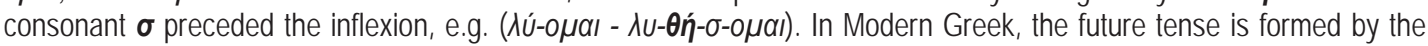
particle $\theta \alpha+$ verb in subjunctive. The initial stages of this verbal form belong to the Hellenistic period, where the structure $\theta \varepsilon \dot{\varepsilon} \lambda \omega$ +infinitive was used as an equivalent form with the future, however, firstly the verb had the connotation of volition, in contrast with that of necessity (R. Browning: 1991, 52). This structure is later replaced with the form $\theta \dot{\varepsilon} \lambda \omega v a+$ subjunctive an analytical form which was later transformed. With the passing of the time, instead of the volition verb $\theta \varepsilon \dot{\lambda} \omega \omega$ its abbreviated form $\theta \varepsilon$ is used, and then it is joined with the particle $v a, \theta \varepsilon v \alpha^{1}$, reaching its final form $\theta a$, product of the

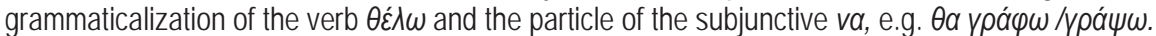

During the evolution of the Albanian language, the particle të is used initially with the subjunctive. The phenomenon occurs also in Greek during the evolution of the verbal system where the subjunctive is preceded by the particle va. Both these particles of the subjunctive have a conjunctive origin for Albanian and Greek.

With regard to the optative, it has its difficulties to be historically argued. There are different viewpoints in terms of its source ${ }^{2}$. The optative of the Ancient Greek has been avoided in the majority of the cases and it is replaced with the subjunctive.

During the development of the Albanian verbal system, new forms were created to express other grammatical meanings as it is the admirative mood, or the non-finite form of the type pa punuar, which are not found in any of the Indo-European languages.

\section{Features of the Albanian and Greek Verbal System}

One of the common features of Albanian and Greek is that both languages have an active and passive conjugation.

In Albanian, the verbs which are used in more than one voice, as it is the case with the majority of the transitive verbs, have both the active and passive voice, whereas intransitive verbs mainly of the middle voice type kollem, have only one type of conjugation - the active conjugation, mainly passive (Akademia e Shkencave të Shqipërisë: 1995, 276).

\footnotetext{
1 In the 12th century, for the first time we see the form $\theta \varepsilon v v a$, (R. Browning: 1991, 109)

2 For more information refer to: Sh. Demiraj, 2002, 376-387.
} 
The forms comprising the paradigm of the verb during its conjugation could be synthetic or analytical.

The synthetic forms of the verb in Albanian are constructed by means of inflexions showing the person and the phonetic changes that the stem undergoes, simultaneously through inflexions and phonetic changes, suffixes which are sometimes complemented with infexions showing the person and through suppletion complemented with inflexions showing the person or suffixes.

On the other hand, in order to form the analytical forms the auxiliary verbs kam and jam for the active and passive respectively are used, and the formant particles të for the subjunctive, duke and pa for the non-finite forms and $u$ for the passive voice etc.

Even in Greek, the verb forms its paradigm both in the active and passive voice.

The synthetic forms in its active and passive conjugations are formed through the inflexions of person-tense, which are added to the stem of the verbs and are different for each conjugation, phonetic changes of the stem of the verb, suffixes and suppletion. In Ancient Greek, the augment and duplication were also used to render the tense and mood forms of the verbs, which are also used in Modern Greek. Here, we include the infinitive and past participle, where the active and passive past participle are different from each other in terms of the inflexions and the verbal stem, with regard to the infinitive, the inflectional endings are the same for both forms $(-\varepsilon l)$, but the verbal stem changes.

In relation to the analytical forms of the active and passive voice, the auxiliary $\varepsilon x \omega$ (have) is used, even though for

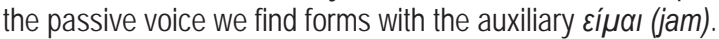

The form and the grammatical category of the voice is a feature of the verbs in both Albanian and Greek languages. Since both languages have an active and passive voice, the verbs (the majority, since there are also verbs used in one form) may be used in both forms, active and passive.

In Albanian, the relation between the action and the subject of the sentence is expressed morphologically with two forms, in contrast with one another, the active and the passive forms of the verb (Akademia e Shkencave të Shqipërisë: 1995). The verbs in active voice in the first person singular of the present tense indicative mood have the ending $-j$, whereas verbs of the second conjugation where the final sound of the stem is a consonant and the verbs of the third conjugation with a vowel as the final sound of the stem do not have any inflexions. In the passive voice first person of the present tense indicative mood the verbs' inflectional endings are $-\mathrm{em} /$-hem.

The analytical tenses of the active voice are formed with the auxiliary kam, whereas those of the passive voice are formed with the auxiliary jam.

Not all the verbs can be used in both forms the active and the passive voice. The majority of transitive verbs which are used in more than one voice are used in both forms, e.g. laj-lahem, mësoj-mësohem etc. The intransitive verbs are used only in passive voice such as pësoj whereas the middle voice type of verbs kollem (coughing) is used only in passive.

Grouping the verbs according to the forms in Greek is based on one criterion, the morphological one, i.e. the form of the verb, therefore, as a distinctive characteristic of the form of the verb serves the inflexion of the first person singular indicative mood. Taking this fact into account, these verbs are grouped in two forms: the active and passive voice ${ }^{3}$.

Verbs of the active voice are those verbs which in the first person singular indicative taken the inflexion - $\omega(-\dot{\omega})$, whereas the verbs of the passive voice in the first person singular indicative take the inflexion $-\mu a$.

Usually the verbs of the active forms belong to active voice and those of the passive forms belong to the middle passive voice. The verbs of the neutral voice may belong to either the active or passive voice e.g. the verb $\zeta \omega$ belongs to the neutral voice of the active voice, whereas the verb koı $\mu a$ $\mu a ı$ belongs to the neutral voice but in passive.

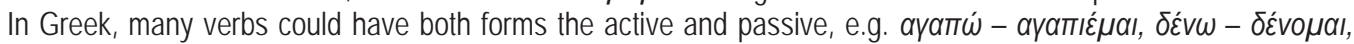

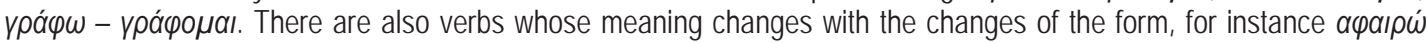

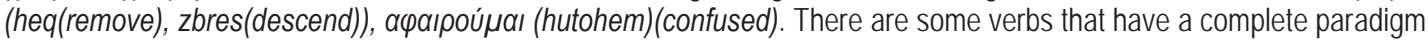

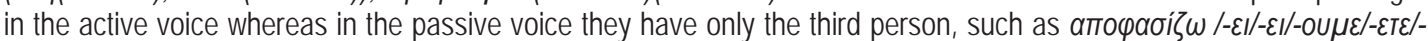

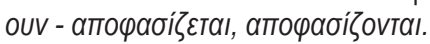

Apart from the verbs which are used in both forms, there are also verbs found only in one form, active or passive,

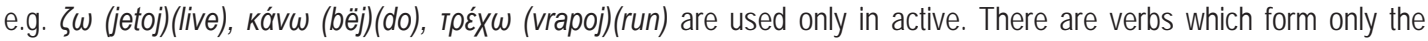
active voice, but they belong to the passive voice such as: $\pi \alpha \theta \alpha i v \omega$ (pësoj) (undergo) or the verb kó $\beta \omega$ (pres) (cut) as in the sentence кó $\beta \omega \tau$ та $\mu \alpha \lambda \lambda$ á $\mu$ ou (pres flokët te berberi) (cut the hair at the barber), which belongs to the passive voice but are used in active. Verbs that are used only in passive voice are called apothetic verbs and some of them belong to

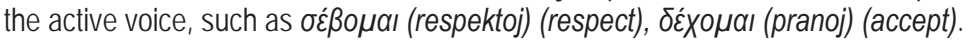

${ }^{3}$ Klairis and Babiniotis use the terms active and medium-passive forms with the argument that the verb in medio-passive expressed

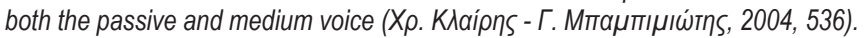


Do the forms of the verbs in Albanian and Greek coincide? In the majority of the cases, they do. Verbs which are active or passive in one language are found in the same form even in the other language, however, there are also cases of inconsistencies; such as the verb kollem (cough) in Albanian is passive whereas in Greek it is active $\beta \eta \operatorname{\eta x} \omega$, similarly

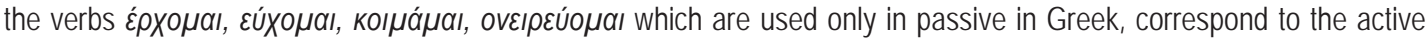
voice verbs in Albanian vij(come), uroj(wish), fle(sleep), ëndërroj(dream) respectively.

The category of the voice is the category which bears the majority of the differences in both languages. The differences start firstly with the definition of this category and the criteria used in each language for the classification of verbs according to the voice.

In Albanian, the voice is a grammatical category which expresses the relation between the action and the subject of the sentence. This relation is expressed morphologically with the active and passive voice ${ }^{4}$. The category of voice belongs to those verbs which can be used in the active and passive forms with their relevant meaning oppositions (Akademia e Shkencave të Shqipërisë: 1995). In the general sense of the word, this category includes all verbs used in active voice, such as the intransitive verbs or the verbs used only in passive form, such as the verbs kollem, dukem, pendohem etc (Akademia e shkencave të Shqipërisë, Instituti i gjuhësisë dhe i letërsisë: 1976). According to the grammar of Albanian language (Akademia e Shkencave të Shqipërisë: 1995, 270), on the basis of the different relations between the action denoted by the verb and the subject of the sentence, as well as the opposition of the relevant forms (active-passive), there are four voices in Albanian: active, passive, reflexive and medium voice.

Active voice verbs have their active forms and denote an action performed by the subject, for example ${ }^{5}$ (1):

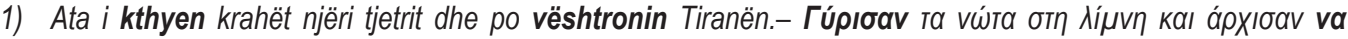
maparnpoúv тa Típava. (They turned their back to each other and were looking at Tirana)

These verbs in Greek belong to the active voice, but the active form is not a criterion to classify them as active or passive, as long as the subject performs the action.

Verbs belong to the passive voice when they have a passive form and denote an action that the subject of the sentence receives, where the agent could be linguistically expressed or not. This category of voice includes all cases when the verbs in passive form denote an action not performed by the subject of the sentence, for example (2):

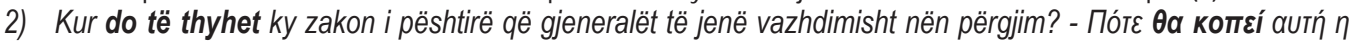

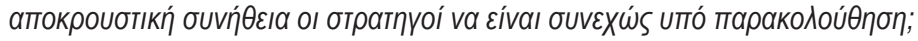

Further, in Greek these verbs belong to the passive voice but they are different from their Albanian equivalents as they comprise even verbs that in active denote an action not performed by the subject but the subject receives the action.

Verbs that belong to the reflexive voice category have their passive forms and denote an action that the subject performs and receives as well. In relation to the reflexive voice category, there is a sub-classification where the subject of the sentence represents the person acting on itself, and the verb is inherently reflexive, e.g. krihem (comb myself), lahem (wash myself), vishem (dress myself). In Greek, these verbs belong to the medium voice category. When the subject stands for two or more person mutually acting on each-other, then the verb is in the mutual reflexive voice, e.g. përqafohem,(hug) përshëndetem (greet), fejohem (get engaged). These verbs in Greek are included in the medium voice category and are called mutual medium voice verbs.

Verbs belonging to the medium voice are in passive form and denote an action performed by the subject. The medium voice category comprises a group of verbs which denote movement such as: hidhem(jump), kthehem(turn), përpiqem(try), rrotullohem(turn over), example (3). In Greek, these verbs are classified under the active voice category because regardless of the form they show that the subject performs the action. Some verbs denoting psychologicalphysiological actions such as: gëzohem,(rejoice) hidhërohem,(grieve) mërzitem,(get bored) kollem (cough) example (4) and some verbs that denote changes in physical, physiological, psychological state of the subject, such as: plakem(get old), rritem(grow), tkurrem(shrink), example (5):

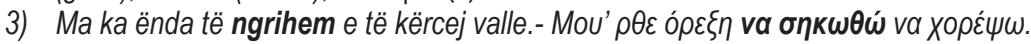

4) Me siguri pati njerëz që u gëzuan sepse bota ka gjithfarë karafilash, por asnjeri nuk guxoi ta shprehte hapur. -

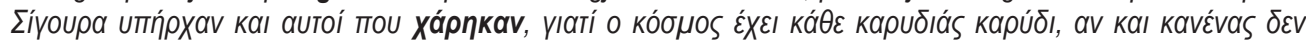

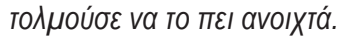

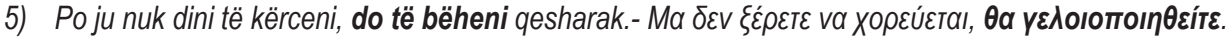

\footnotetext{
${ }^{4} \mathrm{E}$. Likaj gives a different definition for the category of voice: "The grammatical category of voice shows the condition of the subject, expressed by the verb in a certain syntactical form or construction" and according to this definition he groups verbs as active, intransitive, passive, medium or mutual voice. For more information, refer to (E. Likaj, 1970).

${ }^{5}$ The examples are taken from the novel "Gjenerali $i$ ushtrisë së vdekur" of Ismail Kadare, translated in Greek from the original by

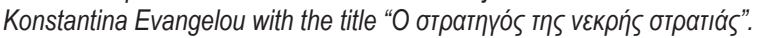


Whereas in Greek, the criterion used to classify verbs according to the voice category is neither a morphological nor a syntactical one, but a semantic criterion related to the meaning of the verb. The voice of the verb means the action,

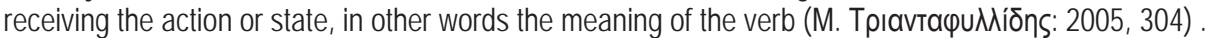

The verb in Greek has four voice categories the active, passive, medium and neutral.

The verbs belonging to active voice are those verbs which denote that the action is performed by the subject, regardless of being in active or passive forms, regardless of being transitive or intransitive. Thus, the form and transitivity

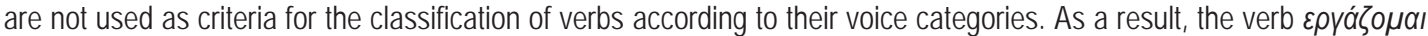

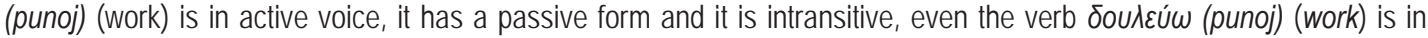
active voice but it has an active form and it is transitive. Active voice includes also the verbs yupí $\omega$ (kthehem)(turn

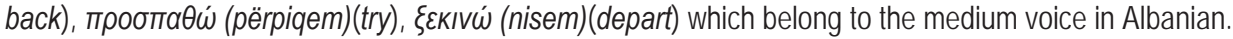

Transitivity and intransitivity are characteristics of the verbs in active voice, thus, they are verbs of active voice even though based on their form they are classified as transitive or intransitive. Transitive verbs of the active voice are those verbs where the action is transferred from one person or object to the other, verbs that are followed by a direct object, whereas intransitive verbs include those verbs where the action is not transferred to another person or object and the verbs are not followed by a direct object.

Passive voice includes those verbs which denote that the subject receives the action, thus denote an action performed by another person or object other than the subject. The majority of these verbs are in passive form, but there are also verbs of active form such as the verb $\pi \alpha \theta a i v \omega$ (pësoj) belonging to the passive voice.

The medium voice category includes those verbs where the subject acts and it is acted upon, e.g. viúvopal

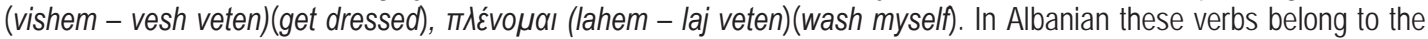
reflexive voice category.

Whereas the neutral voice category includes those verbs which denote that the subject neither acts nor receives

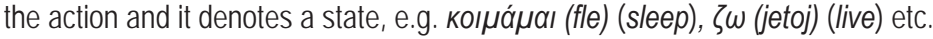

The grammatical category of mood is present in both languages. Albanian is relatively richer in mood forms; we should take into consideration that during its development Greek has avoided the use of some mood forms such as the optative.

In Albanian, the grammatical category of mood is the main means to express modality, which is the property of the non-finite forms of the verbs, different from Greek where the past participle and infinitive are considered as the impersonal forms of the verb ${ }^{6}$. Through the grammatical category of mood the speaker expresses his/her attitude towards the action denoted by the verb, presenting it as true, possible, desirable etc. (Akademia e Shkencave të Shqipërisë: 1995)

In order to express these modality senses, Albanian in its historical development has created special grammatical indicators, which in some cases along with the meaning of the modality they express the meaning of tense (Sh. Demiraj:1986, 698).

In Albanian, the verb is used in six moods: the indicative, admirative, subjunctive, conditional, optative and imperative. Some grammars argue about the so-called subjunctive-admirative mood as a separate mood (O. Myderrizi: 1944, K. Cipo: 1949, Sh. Demiraj: 1961)7. There are also debates and linguists hold different viewpoints in terms of the admirative and conditional moods. Some accept these verb forms as separate moods while others treat them as forms of the indicative mood8. The admirative of the Albanian, in terms of its structure is specific for Albanian and cannot be found in any of the Indo-European languages (Sh. Demiraj: 1986, 906). The forms of the admirative are constructed by the abbreviated past participle form and the auxiliary kam (have). This argument was given for the first time by Doson and has been supported by the majority of linguists ${ }^{9}$, it was not accepted by Jokli who thought that the admirative is constructed from the compounding of the inverted future form, this argument is not well supported as Demiraj also states

\footnotetext{
${ }^{6}$ Even in the previous grammatical tradition of Albanian, the non-finite forms of the verbs the past participle, the infinitive and gerund were treated as the moods of the verbs. However, the linguistics following the year 1945 criticized this viewpoint, as the non-finite forms of the verb do no express the attitude of the speaker in relation to the action denoted by the verb, denoting it as true, possible or desirable etc. (Sh. Demiraj: 1977).

${ }^{7}$ Sh Demiraj në Gramatikën Historike të Gjuhës Shqipe, 1986, 699, 701, is of the opinion that the subjunctive-admirative cannot be considered as a separate mood form.

${ }^{8}$ S. Frashëri and K. Kristoforidhi in their grammars treat the forms of the admirative mood as forms of the indicative and subjunctive; with regard to the conditional mood S. Frashëri and F. Agalliu do not treat it as a separate mood form.

${ }^{9}$ For a more detailed information concerning the construction of the admirative and the linguists who support this opinion, refer to Sh. Demiraj: 1971, 33.
} 
(Sh.Demiraj: 1971, 33 - 34). According to E. Lika, the free syntactical constructions of the type past participle + have which brought about the present forms of the admirative have been used by authors in the past, as they are also used nowadays. For a while, until the respective grammaticalisation was realized, the same syntactical structure was related to two contents, one of them highlighted the action in the past and the other denotes the same action as sudden, while the first meaning was not used and developed further as it was represented by the construction have worked, the second meaning was developed further grammatically (E. Likaj: 1997, 149).

The conditional 10 mood expresses the modality of possibility. The verb in the conditional mood denotes an action that can be performed if the condition is met. The condition is often expresses by a subordinate conditional clause, whose verb is in past progressive tense or in the past perfect of the subjunctive mood.

There are cases when it can be expressed by the adverb ndryshe (different), which would be used with the value of a cleft sentence or by a phrase consisting of the preposition me (with) or pa (without) and a noun (Akademia $\mathrm{e}$ Shkencave të Shqipërisë: 1995, 327).

In Albanian, verbs in optative mood have specific forms through them the speaker expresses a wish in the form of a wish or a curse. According to Demiraj (Sh. Demiraj: 1986, 888), the Albanian optative mood is relatively old, which is demonstrated by its uses in all its known functions in all dialects of Albanian, including here the dialect spoken by the Arberesh of Greece and Italy. There are different viewpoints with regard to how the forms of the verb in optative are structures. According to Meyer and Pekmes the origin of the optative is related to the present perfect of the Latin subjunctive mood, whereas Bopp and Pedersen argue that its origin is related to "aorist" of the subjunctive, this latter opinion is also supported by Domi and Demiraj ${ }^{11}$.

In Greek, the mood means the different forms of the verb to denote the spiritual predisposition of the speaker (M.

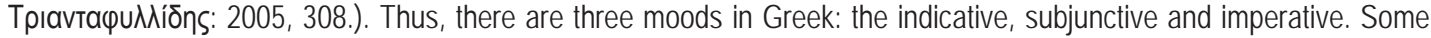

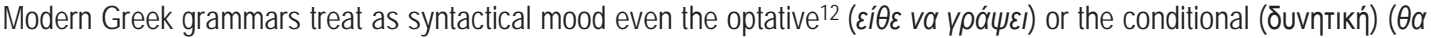
$\varepsilon \gamma \rho a \varphi \alpha)$, which according to Klairis and Babiniotis occurs due to the vagueness of the term mood. As they have stated

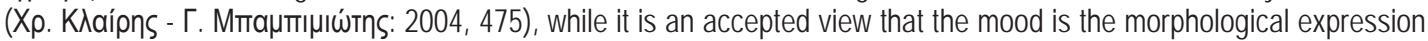
of modality, it is unclear what it is meant with morphological expression. Since in the Indo-European languages the moods are forms traditionally distinguished by their endings, they state that the two moods clearly distinguished from one another are the indicative and imperative. With regard to the subjunctive, it is distinguished on the basis of the stem in the forms that are structured from the aorist stem.

Whereas with regard to the other forms mainly the optative and the conditional, the distinction is based on the endings but through the particles preceding the verbs $(v \alpha, \theta \alpha, \alpha \varsigma)$. Some scholars think that we are not dealing here with

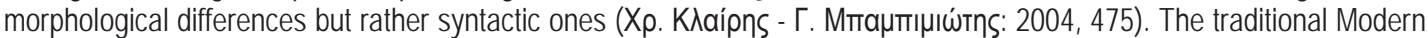

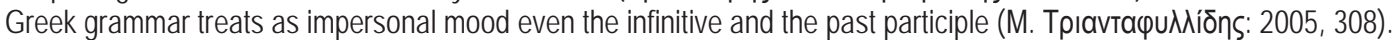

The documented verbal system of Albanian is quite rich in tense forms, which express not only meaning differences of a tense character, but in some cases of an aspect nature as well (Sh. Demiraj: 1986, 708). The grammatical category of tense denotes the relation between the time, when the action denoted by the verb is performed and a certain moment, which is considered as the basis for time relations. This moment in speech is referred to as the moment of the speech, whereas for the written language as the moment when we are writing or another imagined moment. Therefore the main tenses of the verb are three: the present, the past and future (Akademia e Shkencave të Shqipërisë: 1995, 273). On the basis of these three fundamental tenses there is a tense sub-classification. Not all the moods of the verb have the same number of grammatical tenses. This is due to the reason that "the type of modality of one mood or another conditions even the existence or the use of a greater or a smaller number of tense forms" (Sh. Demiraj: 1986, 709) Thus, the Albanian indicative mood, with regard to modality it is less marked ${ }^{13}$ than the other moods, is richer in tense forms. The indicative has ten tense forms: the present, the past progressive, past simple, present perfect, past perfect, past perfect progressive, future simple, future perfect, future simple in the past, future perfect in the past. The admirative mood has four tense forms: the present, the past progressive, present perfect and past perfect. The conditional mood similar to the optative mood has only two tense forms, the present simple and the present perfect; in

\footnotetext{
${ }^{10}$ According to $K$. Topallit, the verbal forms treated as the conditional mood by different grammars, are nothing else but forms of the future simple in the past used hypothetically and cannot be considered as separate mood forms. (K. Topalli: 2010).

${ }_{11}^{11}$ For a more detailed information on the origin of the optative along with the origin of the formant -sh-/ -fsh-, refer to Sh. Demiraj: 1986 , $890-896$.

12 The optative of Ancient Greek, avoided during the development of the language, was expressed with a separate verbal form.

${ }^{13}$ At "Gramatika Historike e Gjuhës Shqipe", 1986, Sh. Demiraj holds the opinion that the indicative mood from the viewpoint of modality is negatively characterized.
} 
relation to the imperative there is not any tense opposition and in its forms do not express the grammatical category of tense (Sh. Demiraj: 1986).

Even in Greek to show the difference between the tenses, specific verb forms are used to denote the grammatical tenses. Similar to Albanian, these tenses are grouped into: simple present tenses, past tenses and future tenses. In Greek, only in the indicative mood these tenses denote the moment that the action is performed. Therefore, the tenses of the indicative are the present simple tense, the past continuous tense, the aorist, the present perfect, the past perfect, simple future tense, future progressive tense and future perfect tense. Similar to Albanian, the tense forms could be synthetically constructed as the present tense, the past progressive and the aorist or analytically (periphrastic) such as the present perfect, past perfect and tenses of the future. Greek grammar makes another classification of the tenses on

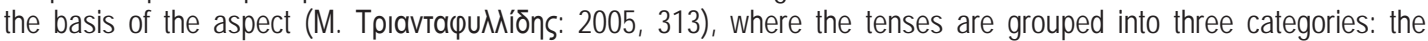
progressive aspect which denotes continuity, duration or the repetition of the action such as the present tense, the past progressive, future progressive; the tenses of the moment or summary, which depict the action in its entirety as it has already occurred or it is about to occur, or they consider the action as it has already happened or it will occur only once and the tenses include the aorist and the simple future tense; and the perfect tenses, presenting the action as completed such as the present perfect, past perfect and future perfect.

The other moods apart from the indicative do not have all the tenses, yet, even those tenses which are present do not determine the moment the action has been performed but the aspect. Thus, the tenses of the subjunctive and imperative mood are distinguished according to the aspect and they are determined on the basis of their base form for these tenses. Therefore, the subjunctive has three tenses, the present formed from the stem of the indicative present and it denotes continuity, the aorist formed from the stem of the verb in indicative aorist and it is a tense of the moment (summarizing) and the present perfect.

The imperative mood has two tenses, the present and the aorist with their respective aspect related distinctions between them. It depends on the context where the tenses are used to determine the time of the action denoted by these tenses.

It is noticed that the Albanian language is relatively richer in mood and tense forms than Greek. Albanian has three mood forms, such as the admirative, the optative and conditional mood, which are absent in Greek grammar and they are treated as modalities. Following, there is a table of the moods and tenses for each language.

Table 1. Moods and tenses in Albanian and Greek

\begin{tabular}{|c|c|c|c|c|c|}
\hline & \multicolumn{2}{|c|}{ Albanian } & \multicolumn{3}{|c|}{ Greek } \\
\hline \multirow{11}{*}{ Indicative } & Present simple & laj & \multicolumn{2}{|l|}{ Present simple } & $\pi \wedge \dot{\varepsilon} V \omega$ \\
\hline & Past progressive & laja & \multicolumn{2}{|l|}{ Past progressive } & 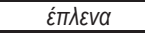 \\
\hline & Past simple & lava & \multicolumn{2}{|l|}{ Aorist } & 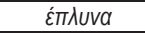 \\
\hline & Present perfect & kam larë & \multicolumn{2}{|l|}{ Present perfect } & 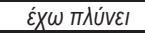 \\
\hline & Past perfect & kisha larë & \multicolumn{2}{|l|}{ Past perfect } & 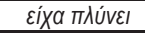 \\
\hline & Past perfect (Pluperfect) & pata larë & \multicolumn{2}{|c|}{-} & - \\
\hline & \multirow{2}{*}{ Future tense } & \multirow{2}{*}{ do të laj } & \multirow{2}{*}{ Future tense } & Simple future tense & $\theta a \pi \lambda \varepsilon ́ v \omega$ \\
\hline & & & & Future progressive & $\theta \alpha \pi \wedge u ́ v \omega$ \\
\hline & Future perfect & do të kem larë & \multicolumn{2}{|l|}{ Future Perfect } & 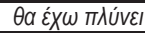 \\
\hline & Future in the past & do të laja & \multicolumn{2}{|c|}{-} & - \\
\hline & Future perfect in the past & do të kisha larë & \multicolumn{2}{|c|}{-} & - \\
\hline \multirow{4}{*}{ Admirative } & Present simple & lakam & \multirow{4}{*}{\multicolumn{3}{|c|}{-}} \\
\hline & Past progressive & lakësha & & & \\
\hline & Present perfect & paskam larë & & & \\
\hline & Past perfect & paskësha larë & & & \\
\hline \multirow{4}{*}{ Subjunctive } & Present simple & të laj & \multicolumn{2}{|l|}{ Present simple } & 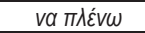 \\
\hline & Past progressive & të laja & \multicolumn{2}{|l|}{ Aorist } & $v a \pi \lambda u ́ v \omega$ \\
\hline & Present perfect & të kem larë & \multicolumn{2}{|l|}{ Present perfect } & 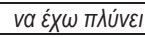 \\
\hline & Past perfect & të kisha larë & \multicolumn{2}{|l|}{-} & - \\
\hline \multirow{2}{*}{ Conditional } & Present simple & do të laja & \multirow{2}{*}{\multicolumn{3}{|c|}{-}} \\
\hline & Present perfect & do të kem larë & & & \\
\hline \multirow{2}{*}{ Optative } & Present simple & lafsha & \multirow{2}{*}{\multicolumn{2}{|c|}{-}} & \\
\hline & Present perfect & paça larë & & & \\
\hline \multirow{2}{*}{ Imperative } & \multirow{2}{*}{$--^{14}$} & \multirow{2}{*}{ laj/lani } & \multirow{2}{*}{$\begin{array}{l}\text { Present simple } \\
\text { Aorist }^{15}\end{array}$} & \multicolumn{2}{|c|}{$\pi \Lambda \varepsilon^{\prime} \vee \varepsilon / \pi \lambda \varepsilon^{\prime} V \varepsilon T \varepsilon$} \\
\hline & & & & $\pi \lambda u ́ l$ & 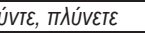 \\
\hline
\end{tabular}

14 In Albanian the forms of the imperative mood do not form a tense opposition, in this sense we cannot talk about a tense grammatical category. 


\section{The Issue of Aspect}

In Albanian the aspect of the verb is not treated as an inherent grammatical category. In the Albanian language grammar (Akademia e Shkencave të Shqipërisë: 1995) this term is used, for instance, to show the difference between the past simple tense, the past progressive and past perfect "which has a stronger aspect nature". The same grammar book states that "the category of aspect is based on the opposition performed action vs. non performed action which is expressed with the relevant grammatical forms in all the paradigm of the verbal system. The grammatical category of aspect is not developed in the verbal system of the Albanian language, which is characterized by the grammatical category of tense. However, some verbal forms of this system are distinguished from one another depending on the aspect connotation". In an earlier stage of Albanian, the different forms of the aspect have existed which were expressed by specific endings, which are lost by turning the previous aspect system into a tense system, however, some verb forms have preserved their aspect character, for example the present tense and progressive tense have an imperfective character, while the past tense has a perfective character (K. Topalli: 2010, 58, 212).

Different from Albanian, the aspect has a significant place in Greek. Since the beginning the tenses of the verb where used to express the aspect (the type and manner of performing the action denoted by the verb: continuous, of the

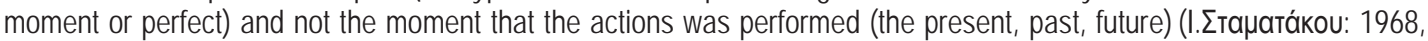
83).

The aspect related distinction between the tenses is still present even in Modern Greek. Mirambel stresses that the aspect distinction prevails over the mood and tense distinction ('Mirambel: 1942, 28, quoted by P. Mackridge: 1990). But, the scholars do not use a unified terminology to describe this category of the verb in Greek. Triantafilidhis (2005,

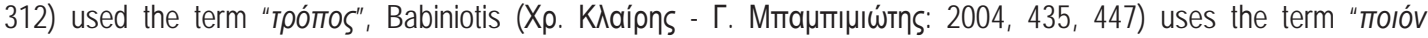

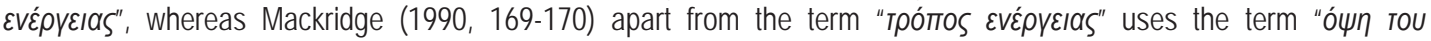

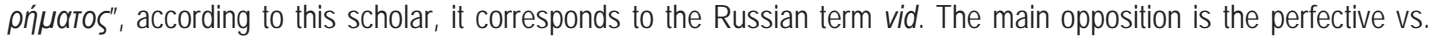
imperfective aspect ${ }^{16}$ but there might also be the perfect aspect, which is a feature of the verbs in present perfect, past perfect, future perfect of the indicative mood. The perfective aspect is a feature of the verbs in the present tense in all moods, indicative, subjunctive and imperative, the past progressive and the future progressive of the indicative, while the imperfective aspect is that of the verbs in aorist in all the moods mainly, indicative, subjunctive and imperative and in the simple future of the indicative.

As a conclusion, we could say that the verbs both in Albanian and Greek have a variety of grammatical forms according to a certain paradigm while they are used. The verbal system of both languages has developed from that of the Indo-European language by preserving in some cases some of its features, and in other cases it has had an independent development in each language. We could identify many common features along with many peculiarities as the grammatical category of the verb is concerned.

\section{References}

Akademia e Shkencave të Shqipërisë (1995) Gramatika e gjuhës shqipe, Tirana.

Akademia e Shkencave të Shqipërisë, Instituti i gjuhësisë dhe i letërsisë (1976) Fonetika dhe gramatika e gjuhës së sotme letrare shqipe II, Tirana.

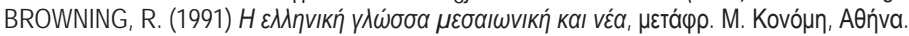

CIPO, K. (1949) Gramatika shqipe, Tirana.

DEMIRAJ, SH. (2004) Gjuhësi ballkanike, Tirana.

(2002) Gramatikë historike e gjuhës shqipe, Tirana.

(1977) Rreth kategorive gramatikore të mënyrës dhe të kohës në gjuhën shqipe, Studime Filologjike 3, Tirana.

(1976) Morfologjia historike e gjuhës shqipe, Pjesa II, Tirana.

(1971) Habitorja dhe mosha e saj, Studime Filologjike 3, Tirana.

(1961) Morfologjia e gjuhës së sotme shqipe (II), Tirana.

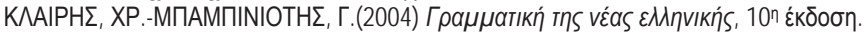

Likaj, E. (1997) Format analitike në gjuhën shqipe, Tirana.

(1970) Disa çështje të kategorisë së diatezës në gjuhën shqipe, Studime Filologjike 4, Tirana.

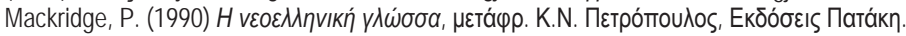

Myderrizi, O. (1944) Gramatika e re e shqipes, Tirana.

Topalli, K. (2010) Sistemi foljor i gjuhës shqipe, Tirana.

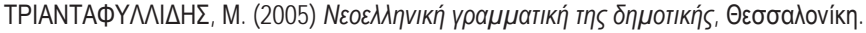

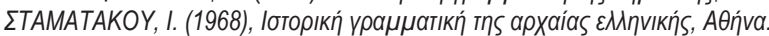

${ }^{15}$ There are rare cases when the present perfect is present in the imperative mood in Greek: $\chi_{\chi \varepsilon} \Pi \lambda u \mu \varepsilon ́ v 0$.

${ }^{16}$ Even the terminology describing the type of aspect in Greek is not entirely unified. 